\title{
Effects of supplementing a mixed diet with echium (Echium plantagineum) oil on methanogenesis in a rumen simulation system
}

\author{
P. Amaro' ${ }^{1}$ M.R.G. Maia ${ }^{1}$, R.J. Dewhurst ${ }^{2}$, A.J.M. Fonseca ${ }^{1}$ and A.R.J. Cabrita ${ }^{1,3}$ \\ ${ }^{1}$ Universidade do Porto, REQUIMTE, ICBAS, Institute of Biomedical Sciences de Abel Salazar \\ Jorge Viterbo Ferreira Street 228, 4050-313 Porto, Portugal \\ ${ }^{2}$ Scotland's Rural College, King's Buildings, West Mains Road, Edinburgh EH9 3JG, United Kingdom
}

KEY WORDS: Echium plantagineum oil, methane inhibitors, rumen fermentation

Received: 4 March 2014

Revised: 5 February 2015

Accepted: 16 March 2015

${ }^{3}$ Corresponding author:

e-mail: arcabrita@icbas.up.pt

\begin{abstract}
The rumen simulation technique (RUSITEC) was used to evaluate the effect of two levels of echium (Echium plantagineum) oil (EO) on methano-genesis. Treatments comprised: control (commercial total mixed ration for lactating dairy cows; positive control), control supplemented with sodium 2-bromoethanesulfonate ( $5 \mathrm{mM}$ on a dry matter (DM) basis; negative control; $\mathrm{BES}$ ) and control supplemented with $4 \%$ (EO4) and $8 \%$ (EO8) of echium oil $\left(\mathrm{g} \cdot 100^{-1} \mathrm{~g} \mathrm{DM}\right)$. Methane production and the proportion of methanogens in total rumen prokaryote $16 \mathrm{~S}$ rDNA from effluents and solid residues were decreased by EO8. Oil supplementation did not affect total volatile fatty acid production and digestibility of DM and neutral detergent fibre, but increased propionate proportion. Despite the in vitro results suggesting that echium oil is a promising natural strategy for the mitigation of enteric methane, it is difficult to distinguish whether the observed effects are due to secondary metabolites, a particular fatty acid, or mixtures of fatty acids contained in the echium oil.
\end{abstract}

\section{Introduction}

Enteric methane is produced by Archaea which convert carbon dioxide and hydrogen originating from the rumen fermentation of feedstuffs into methane. Although methanogenesis prevents negative effects of hydrogen accumulation in the rumen, methane emissions have a detrimental effect on the environment and represent a substantial non-productive loss of energy from the animal (e.g., Johnson and Johnson, 1995). Dietary supplementation with lipids is one of several strategies that have been studied to reduce rumen methanogenesis. Supplementation with medium- and long-chain fatty acids can decrease methane emissions due to a direct inhibition of methanogenic Archaea or to an indirect action on the wider microbial community leading to a reduction in fermentable organic matter (Martin et al., 2010). Additionally, vegetable oils rich in polyunsaturated fatty acids (PUFA) can have a toxic effect on the rumen microbial population and provide an alternative electron sink for hydrogen through biohydrogenation (Prins et al., 1972; Czerkawski, 1986).

Echium oil is a vegetable oil extracted from the seeds of Echium plantagineum, and is one of the richest sources of stearidonic acid (SDA; C18:4n-3; Guil-Guerrero, 2007). Earlier studies have showed 
the potential use of soyabean oil with elevated levels of SDA (Bernal-Santos et al., 2010) and protected echium oil (protein-aldehyde matrix; Kitessa and Young, 2011) to increase the $n$-3 PUFA content in dairy products. Eicosapentaenoic acid (C20:5n-3) and docosahexaenoic acid (C22:6n-3) are longchain $n$-3 PUFA known to have beneficial effects on human health (Calder, 2006; Mozaffarian, 2008). These $n-3$ long-chain PUFA are synthesized from $\alpha$-linolenic acid (C18:3n-3) by a sequence of desaturation and chain elongation steps. Nevertheless, $\mathrm{C} 18: 3 n-3$ is poorly converted to $\mathrm{C} 20: 5 n-3$ partly because of the low activity of $\Delta 6$-desaturase, the rate limiting enzyme for conversion (C18:3n-3; Yamazaki et al., 1992). Conversely, as SDA is downstream from $\Delta 6$-desaturase, it is more readily converted to C20:5n-3 (Kitessa et al., 2014).

Recently, we (Amaro et al., 2012) evaluated the effect of increasing levels of SDA $(0,1,5,20$ and $50 \mathrm{mg} \cdot \mathrm{l}^{-1}$ incubation media) on methane production in short-term batch incubations with buffered rumen fluid. Despite the observed shift to increased propionate production at the expense of acetate and butyrate, and the extensive apparent biohydrogenation of SDA, there was no significant reduction in methanogenesis. These results suggest that either higher levels of non-esterified SDA or its supplementation in alternative forms might be needed to achieve methane mitigation. Along with its relatively high SDA content, echium oil is also rich in C18:3n-3 and linoleic acid (C18:2n-6), known to have potential to decrease methanogenesis (Czerkawski et al., 1966; Zhang et al., 2008). To our knowledge, the potential of echium oil in decreasing methane production has never been reported. Therefore, the present work aimed to evaluate, in an in vitro semi-continuous fermentation system (RUSITEC system), the effects of two levels of echium oil supplementation on ruminal methanogenesis and fermentation.

\section{Material and methods}

\section{Animals}

Rumen contents were collected from commercial dairy cows after slaughter at an authorized slaughterhouse (Central Carnes abattoir, Vila Nova de Famalicão, Portugal). Animals were protected at slaughter according to the Council Directive 93/119/ EC of 22 December 1993 and rumen content collection for experimental purposes was done by qualified members as previously authorized by the Portuguese National Authority for Animal Nutrition and Health (Direção Geral de Alimentação e Veterinária) of the Ministry for Agriculture, Sea, Environment and Spatial Planning (Ministério da Agricultura, do Mar, do Ambiente e do Ordenamento do Território, Portugal).

\section{Semi-continuous in vitro incubation}

A rumen simulation technique (RUSITEC) system, with eight $800 \mathrm{ml}$ vessels (RUSITEC S, Sanshin Industrial Co. Ltd., Yokohama, Japan), was used as described by Czerkawski and Breckenridge (1977). The inoculum was obtained from three adult dairy cows fed maize silage-based diets immediately after slaughter. Solid and liquid fermentation inocula were placed in a pre-heated thermos container at $39^{\circ} \mathrm{C}$ for transport to the laboratory and transferred to the RUSITEC system within less than $1 \mathrm{~h}$. At the laboratory, the ruminal digesta was mixed, strained through 4 layers of linen-cloth and maintained at $39^{\circ} \mathrm{C}$ under $\mathrm{O}_{2}$-free $\mathrm{CO}_{2}$.

Two identical 12 days incubation trials were carried out independently and the four treatments were assigned randomly within each trial, so that two fermenters received each of the treatments with two replicates per treatment; each treatment was, therefore, performed in quadruplicate. To ensure a steady state within the vessels, each of the two incubation trials consisted of 4 days for stabilization followed by 8 days of data collection. A period serving for the adaptation of the rumen microbes to the fermentation system and diet has been previously found to be the best compromise due to the constraints to extend the experimental periods over more days (Machmüller et al., 1998).

On the first day of each period, vessels were incubated with $500 \mathrm{ml}$ strained rumen fluid, $300 \mathrm{ml}$ artificial saliva (McDougall, 1948), $70 \mathrm{~g}$ strained rumen solids and $12 \mathrm{~g}$ basal diet (dry matter, DM, basis) placed in individual nylon bags $(80 \times 120 \mathrm{~mm}$, $50 \mu \mathrm{m}$ pore size; Sanshin Industrial Co. Ltd., Yokohama, Japan). The basal diet was a commercial total mixed ration (TMR) for lactating dairy cows, with $491 \mathrm{~g}$ maize silage, $85 \mathrm{~g}$ wheat straw and $424 \mathrm{~g}$ concentrate mixture (per kg, DM basis; Table 1), dried at $65^{\circ} \mathrm{C}$ for $48 \mathrm{~h}$ and milled through a $4 \mathrm{~mm}$ sieve.

After $24 \mathrm{~h}$ of incubation, the bag containing rumen solids was replaced by a bag containing the basal diet. Each vessel contained two feed bags that remained in the system for $48 \mathrm{~h}$, with alternate bags replaced every $24 \mathrm{~h}$. Treatments were introduced on day 5 and were fully implemented from day 6 onwards. The four treatments were each allocated to two fermenter vessels: control (basal diet; positive control), control supplemented with sodium 2-bromoethanesulfonate $(5 \mathrm{mM}$ on a $\mathrm{DM}$ 
Table 1. Composition of the total mixed ration (TMR) used as substrate

\begin{tabular}{|c|c|}
\hline Item & TMR \\
\hline \multicolumn{2}{|l|}{ Ingredient, $\mathrm{g} \cdot \mathrm{kg}^{-1} \mathrm{DM}$} \\
\hline maize silage & 491 \\
\hline wheat straw & 84.7 \\
\hline \multicolumn{2}{|l|}{ Concentrate mixture } \\
\hline maize grain & 123 \\
\hline barley & 8.85 \\
\hline wheat bran & 19.8 \\
\hline soyabean meal & 157 \\
\hline rapeseed meal & 50.9 \\
\hline sunflower meal & 7.78 \\
\hline expeller palm kernel meal & 7.43 \\
\hline calcium soaps & 11.44 \\
\hline molasses & 9.19 \\
\hline urea & 2.54 \\
\hline slow release urea ${ }^{1}$ & 1.69 \\
\hline calcium carbonate & 9.18 \\
\hline dicalcium phosphate & 2.97 \\
\hline salt & 2.12 \\
\hline sodium bicarbonate & 5.51 \\
\hline magnesium oxide & 2.12 \\
\hline mineral-vitamin premix ${ }^{2}$ & 2.54 \\
\hline \multicolumn{2}{|c|}{ 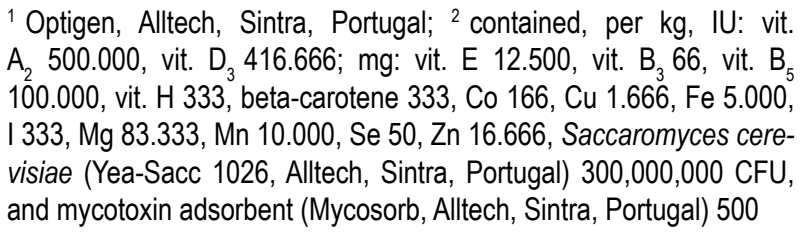 } \\
\hline
\end{tabular}

basis; negative control; BES), and control supplemented with 4\% (EO4) and 8\% (EO8) of echium oil (w/w). Sodium 2-bromoethanesulfonate was used as a negative control as it is a halogenated analogue of coenzyme-M that inhibits methanogenesis by suppressing the methyl-coenzyme $\mathrm{M}$ reductase in Archaea (Balch and Wolfe, 1979; Zhang and Yang, 2011). The supplements were added daily to the basal diet just prior to the introduction of feed bags into the RUSITEC vessels.

The system was flushed with $\mathrm{O}_{2}$-free $\mathrm{CO}_{2}$ during the daily exchange of feed bags. Artificial saliva was continuously infused at a rate of $0.0451 \cdot \mathrm{h}^{-1}$ and gas and liquid effluents collected daily in gas-tight collection bags (Tedlar bag, Tokyo Deodorant Co., Tokyo, Japan) and in flasks placed in an ice-cold water-bath, respectively. Daily total gas production from each fermenter was measured with a dry gas meter (model DC-1A, Shinagawa Corporation, Tokyo, Japan) and $5 \mathrm{ml}$ samples collected for determination of gas composition. The $\mathrm{pH}$ (electrode 5029) and redox potential (electrode ORP 5058) of fermentation media were measured when vessels were opened for exchange of feed bags. Measurements of
$\mathrm{pH}$ were also made in effluents (GLP22+ $\mathrm{pH}$ meter, Crison Instruments, Spain). Liquid effluent was collected and ammonia- $\mathrm{N}\left(\mathrm{NH}_{3}-\mathrm{N}\right)$ and volatile fatty acids (VFA) concentrations were determined. For VFA analysis, $1 \mathrm{ml}$ effluent was added to $0.25 \mathrm{ml}$ $25 \%$ ortho-phosphoric acid solution with internal standard (16 mM 3-methyl valeric acid; Sigma-Aldrich Inc., St. Louis, MO, USA) and kept at $-20^{\circ} \mathrm{C}$. For determination of $\mathrm{NH}_{3}-\mathrm{N}$ concentration, $10 \mathrm{ml}$ of effluent was added to $10 \mathrm{ml}$ of $0.1 \mathrm{M} \mathrm{HCl}$ solution and samples were kept at $4^{\circ} \mathrm{C}$ until analysis.

The feed bag residues were collected during the adaptation and the experimental days and kept at $-20^{\circ} \mathrm{C}$ until further analysis. Apparent DM and neutral detergent fibre (assayed with a heat stable amylase and expressed exclusive of residual ash; NDF) digestibilities determined in whole residue were performed on days 3, 4, 8 and 9; and the proportion of methanogens in the total prokaryote population was determined on days $5,10,11$ and 12 .

\section{Chemical analysis}

The chemical composition (DM, ash, NDF, Kjeldahl N, ether extract, starch and urea) of the basal diet and fatty acids in the basal diet and echium oil were performed as described by Amaro et al. (2012).

Feed bags were rinsed with cold water in a washing machine, dried at $65^{\circ} \mathrm{C}$ for $48 \mathrm{~h}$, and weighed to determine DM apparent digestibility and further NDF apparent digestibility (method 973.18; AOAC, 1990). Effluent $\mathrm{NH}_{3}-\mathrm{N}$ concentration was determined by titration after Kjeldahl steam distillation (method 954.01; AOAC, 1990) and VFA concentrations, gas composition and methane concentration analysed by gas chromatography (Amaro et al., 2012).

\section{DNA extraction and Real-Time PCR analysis}

Feed residues and effluent samples were freezedried and composited for each fermenter vessel across experimental days and across vessels for the adaptation period. Total genomic DNA was extracted after homogenization and physical disruption using a bead beater (Mini-bead Beater, BioSpec Products, Bartlesville, OK, USA), following the method described by Yu and Morrison (2004) with the modification of a higher temperature $\left(85^{\circ} \mathrm{C}\right)$ at the cell lysis step. The concentration of DNA in the extract was measured by spectrophotometry (Nanodrop ND-1000, Nanodrop Technologies, Wilmington, DE, USA).

Quantitative Real-Time PCR (qPCR) was performed on a 7500 Fast Real-Time PCR System (Applied Biosystems, Dublin, Ireland), with fluo- 
rescence detection of SYBR Green dye. The primer sets used in the present study to amplify partial 16S rRNA gene regions of the microbial genome were selected on the basis of a thorough review of the published literature (e.g., Edwards et al., 2005). The chosen V3 and the methanogen morA primers were described by Muyzer et al. (1993) and Denman et al. (2007), respectively. Despite being designed for denaturing gradient gel electrophoresis, V3 primers have been successfully used in qPCR (Brankatschk et al., 2012; Carberry et al., 2012). Extracted DNA was diluted to a concentration of $1 \mathrm{ng} \cdot 1^{-1}$ and used as a template in all PCRs. Polymerase chain reactions were done in triplicate, using $20 \mu \mathrm{l}$ reaction mixtures of $1 \mu \mathrm{l}$ DNA, $10 \mu \mathrm{l}$ Fast SYBR ${ }^{\circledR}$ Green Master Mix (Applied Biosystems, Dublin, Ireland), $1 \mu$ forward and reverse primers $(10 \mu \mathrm{M})$ and $8 \mu \mathrm{l}$ nuclease-free water. The programme used for qPCR was as follows: 1 cycle at $95^{\circ} \mathrm{C}$ for $20 \mathrm{~s}$ for enzyme activation, 40 cycles at $95^{\circ} \mathrm{C}$ for $3 \mathrm{~s}$ and $60^{\circ} \mathrm{C}$ for $30 \mathrm{~s}$, followed by 1 cycle at $95^{\circ} \mathrm{C}$ for $15 \mathrm{~s} 60^{\circ} \mathrm{C}$ for $1 \mathrm{~min}, 95^{\circ} \mathrm{C}$ for $15 \mathrm{~s}$, and $65^{\circ} \mathrm{C}$ for $15 \mathrm{~s}$. Negative controls without template DNA were included in parallel.

Due to the inconsistency in the concentration of PCR inhibitors in each sample, the efficiency of the reaction to ensure correct quantitation was estimated. From an initial concentration of $10 \mathrm{ng} \cdot \mu \mathrm{l}^{-1}$ of DNA, five serial dilutions (10-fold) were performed. Amplification efficiencies (E) were estimated from a linear regression of the threshold cycle (CT) for each dilution versus the log dilution using the formula: $\mathrm{E}=\left[10^{\wedge}[-(1 /\right.$ slope $\left.)-1]\right] \times 100$. Efficiency for the V3 primer ranged from $94 \%$ to $101 \%$ and $86 \%$ to $94 \%$, respectively, for effluents and residues. Efficiency for mcrA primers varied between $93 \%$ to $101 \%$ and $93 \%$ to $99 \%$, respectively, for effluents and residues. The slope varied between -3.3 and -3.5 for $\mathrm{V} 3$ and mcrA in the effluent samples and between -3.5 and -3.8 , and -3.3 and -3.5 , respectively, for V3 and morA in residues. R2 was 0.99 in effluents for both primers and ranged between 0.98 and 1 , and 0.99 and 1 in residues, respectively, for V3 and mcrA. Methanogen population was estimated as a proportion of total rumen prokaryote $16 \mathrm{~S}$ rDNA, according to Zhang et al. (2008): $\Delta \mathrm{Ct}=\left(2-(\mathrm{Ct}\right.$ methanogenes $-\mathrm{Ct}$ total bacteria $\left.) \times 10^{3}\right)$.

\section{Statistical analysis}

All data were analysed using the MIXED procedure of the SAS (2002) software (version 9.1, SAS Institute Inc., Carry, NC). The statistical model included the fixed effect of treatment (control, BES, EO4 and EO8), and the random effect of period.
Adaptation days measurements were used as covariates, the covariance structure being chosen according to Akaike and Schwarz's Bayesian information criteria (Wang and Goonewardene, 2004). Covariates were removed from the model when their effect was not significant $(P>0.15)$. Orthogonal contrasts were constructed for all data in order to compare effects between treatments. Effects were considered significant when $P \leq 0.05$ and a trend when $0.05<P \leq 0.10$.

\section{Results}

The TMR used in the experiment contained (on a DM basis) $179 \mathrm{~g} \cdot \mathrm{kg}^{-1}$ crude protein (Kjeldahl $\mathrm{N} \times 6.25 ; \mathrm{CP}), 383 \mathrm{~g} \cdot \mathrm{kg}^{-1} \mathrm{NDF}$ and $252 \mathrm{~g} \cdot \mathrm{kg}^{-1}$ starch, the major fatty acids found being C16:0, cis-9 C18:1 and C18:2n-6 (Table 2). Echium oil contained $15 \%$ SDA, other fatty acids present in significant amounts being cis-9 C18:1, C18:2n-6, C18:3n-6 and C18:3n-3 (Table 2).

The addition of $8 \%$ echium oil (EO8) and BES decreased total gas production, as well as production of methane. Methane was only detected from day 3 of the experimental period in the fermenters with BES (data not shown). The proportion of methanogens

Table 2. Chemical composition and fatty acid profile of the total mixed ration (TMR) and echium oil

\begin{tabular}{|c|c|c|}
\hline Item & TMR & Echium oil \\
\hline Dry matter (DM), $\mathrm{g} \cdot \mathrm{kg}^{-1}$ & 970 & \\
\hline \multicolumn{3}{|c|}{ Chemical composition, $\mathrm{g} \cdot \mathrm{kg}^{-1} \mathrm{DM}$} \\
\hline ash & 65.0 & \\
\hline crue protein & 179 & \\
\hline ether extract & 30.0 & \\
\hline NDF & 383 & \\
\hline starch & 252 & \\
\hline urea & 5.40 & \\
\hline \multicolumn{3}{|c|}{ Fatty acids, $\mathrm{g} \cdot 100 \mathrm{~g}^{-1}$ total fatty acids } \\
\hline $\mathrm{C} 12: 0$ & 1.32 & - \\
\hline $\mathrm{C} 14: 0$ & 1.12 & - \\
\hline $\mathrm{C} 16: 0$ & 22.2 & 6.88 \\
\hline cis-9 C16:1 & 0.418 & 0.080 \\
\hline C18:0 & 2.33 & 3.14 \\
\hline cis-9 C18:1 & 23.5 & 14.4 \\
\hline cis-11 C18:1 & 1.83 & 0.640 \\
\hline C18:2n-6 & 39.7 & 13.3 \\
\hline C18:3n-6 & - & 10.8 \\
\hline $\mathrm{C} 20: 0$ & 0.329 & - \\
\hline C18:3n-3 & 6.29 & 34.8 \\
\hline C18:4n-3 & 0.409 & 15.0 \\
\hline other fatty acids ${ }^{1}$ & 0.531 & 1.18 \\
\hline
\end{tabular}

${ }^{1}$ the remaining unidentified fatty acids 
Table 3. Mean effects of basal diet (control), control supplemented with sodium 2-bromoethanesulfonate (5 mM DM basis; negative control; BES), and control supplemented with $4 \%$ (EO4) and $8 \%$ (EO8) of echium oil ( $\mathrm{g} \cdot 100 \mathrm{~g}^{-1} \mathrm{DM}$ ) incubated in a long-term semi-continuous fermentation system with buffered rumen fluid (RUSITEC) on gaseous emissions, proportion of methanogens, $\mathrm{pH}$, ammonia- $\mathrm{N}\left(\mathrm{NH}_{3}-\mathrm{N}\right)$ concentration, and volatile fatty acid (VFA) concentration and proportions

\begin{tabular}{|c|c|c|c|c|c|c|c|c|c|c|c|}
\hline \multirow{2}{*}{ Indices } & \multicolumn{4}{|c|}{ Treatment } & \multirow{2}{*}{ SEM } & \multicolumn{6}{|l|}{ Contrast } \\
\hline & Control & BES & EO4 & E08 & & CvsBES & BESvsEO4 & BESvsEO8 & CvsEO4 & CvsEO8 & EO4vsEO8 \\
\hline \multicolumn{12}{|l|}{ Gaseous emissions } \\
\hline total gas, ml & 2108 & 1773 & 2302 & 1680 & 272.1 & 0.038 & 0.003 & 0.524 & 0.201 & 0.012 & 0.001 \\
\hline methane, ml & 138 & 8 & 134 & 57 & 34.7 & 0.001 & 0.001 & 0.097 & 0.906 & 0.014 & 0.018 \\
\hline methane $\cdot$ total gas ${ }^{-1}, \%$ & 6.25 & 0.47 & 5.48 & 3.21 & 0.984 & $<0.001$ & $<0.001$ & $<0.001$ & 0.107 & $<0.001$ & $<0.001$ \\
\hline \multicolumn{12}{|l|}{ Methanogens ${ }^{1}$} \\
\hline effluents & 1.96 & 0.33 & 2.27 & 0.69 & 0.450 & $<0.001$ & $<0.001$ & 0.337 & 0.409 & 0.004 & 0.001 \\
\hline residues & 1.38 & 0.29 & 1.01 & 0.75 & 0.222 & 0.002 & 0.024 & 0.124 & 0.212 & 0.043 & 0.359 \\
\hline \multicolumn{12}{|l|}{ Fermenter vessels } \\
\hline $\mathrm{pH}$ & 6.67 & 6.69 & 6.68 & 6.71 & 0.112 & 0.633 & 0.876 & 0.557 & 0.747 & 0.296 & 0.460 \\
\hline redox, mV & -322 & -311 & -323 & -322 & 2.0 & 0.002 & 0.001 & 0.003 & 0.870 & 0.760 & 0.641 \\
\hline \multicolumn{12}{|l|}{ Effluents } \\
\hline $\mathrm{pH}$ & 6.71 & 6.69 & 6.66 & 6.66 & 0.073 & 0.566 & 0.384 & 0.236 & 0.139 & 0.097 & 0.801 \\
\hline $\mathrm{NH}_{3}-\mathrm{N}, \mathrm{mg} \cdot \mathrm{ml}^{-1}$ & 135 & 111 & 148 & 130 & 18.4 & 0.034 & 0.003 & 0.082 & 0.224 & 0.621 & 0.100 \\
\hline Total VFA, $\mathrm{mmol} \cdot \mathrm{H}^{-1}$ & 65.9 & 62.5 & 68.2 & 69.2 & 11.11 & 0.483 & 0.249 & 0.181 & 0.640 & 0.504 & 0.829 \\
\hline \multicolumn{12}{|c|}{ Molar proportion, $\mathrm{mol} \cdot 100 \mathrm{~mol}^{-1}$} \\
\hline acetate & 48.9 & 47.6 & 48.9 & 47.3 & 2.04 & 0.523 & 0.485 & 0.857 & 0.970 & 0.449 & 0.401 \\
\hline propionate & 20.9 & 20.6 & 22.5 & 24.3 & 2.66 & 0.823 & 0.097 & 0.004 & 0.140 & 0.006 & 0.110 \\
\hline isobutyrate & 1.05 & 0.82 & 1.00 & 0.90 & 0.051 & 0.003 & 0.014 & 0.202 & 0.388 & 0.031 & 0.143 \\
\hline butyrate & 17.9 & 19.1 & 17.5 & 15.8 & 3.26 & 0.369 & 0.251 & 0.023 & 0.788 & 0.116 & 0.181 \\
\hline isovalerate & 3.86 & 4.74 & 4.01 & 4.51 & 0.141 & 0.001 & 0.003 & 0.274 & 0.495 & 0.008 & 0.027 \\
\hline valerate & 4.95 & 5.45 & 5.23 & 5.85 & 0.598 & 0.527 & 0.779 & 0.615 & 0.723 & 0.282 & 0.465 \\
\hline isocaproate & 0.04 & 0.06 & 0.04 & 0.04 & 0.022 & 0.084 & 0.133 & 0.055 & 0.711 & 0.804 & 0.541 \\
\hline caproate & 1.49 & 1.32 & 1.25 & 1.22 & 0.369 & 0.407 & 0.741 & 0.635 & 0.254 & 0.204 & 0.885 \\
\hline acetate:propionate & 2.40 & 2.34 & 2.26 & 1.96 & 0.152 & 0.732 & 0.656 & 0.043 & 0.435 & 0.023 & 0.094 \\
\hline \multicolumn{12}{|l|}{ Digestibility, \% } \\
\hline dry matter & 75.9 & 74.9 & 74.7 & 75.3 & 2.19 & 0.710 & 0.951 & 0.869 & 0.665 & 0.835 & 0.821 \\
\hline NDF & 47.8 & 42.6 & 45.8 & 44.4 & 4.49 & 0.436 & 0.626 & 0.783 & 0.755 & 0.605 & 0.829 \\
\hline
\end{tabular}

${ }^{1}$ methanogens estimated as a $\%$ of total bacterial $16 \mathrm{~S}$ rDNA; $\Delta \mathrm{Ct}=\left(2-\right.$ (Ct methanogenes $-\mathrm{Ct}$ total bacteria) $\left.\times 10^{3}\right)$

within the prokaryote DNA isolated from effluents and residues was lower for the EO8 and BES treatments, the effect of EO8 also being similar to EO4 for residues (Table 3). Treatments had no effect on the $\mathrm{pH}$ of fermenter vessels or effluents, or on DM and NDF digestibilities, but BES treatment increased redox potential and decreased $\mathrm{NH}_{3}-\mathrm{N}$ production (Table 3). Total VFA concentration was not affected by treatments. Propionate proportion was higher for the EO8 treatment compared to the control and BES treatment, no differences being observed for EO4. The acetate:propionate ratio decreased with EO8 relative to control and BES, though it was not different from EO4.

\section{Discussion}

Echium plantagineum is mainly known as a weed of pastures found in regions of the world with a Mediterranean-type climate. It is grown commercially in Europe as a winter annual plant (occasionally biennial) and is readily eaten by livestock in the early stages of growth (Cabi, 2014). The key problem associated with E. plantagineum, is that it contains pyrrolizidine alkaloids that can cause hepatotoxic photosensitization and animal mortality, monogastric animals being more susceptible to alkaloid poisoning. Echium plantagineum is currently one of the best agricultural source of SDA and C18:3n-3, quite valuable 
as health supplements to humans, constituting a potential alternative to marine oils as dietary sources of $n$-3 PUFA (Surette et al., 2004). Echium oil has many potential uses in the pharmaceutical industry for treatment of eczema, acne and other skin disorders, and it is also valued for its moisturizing and anti-inflammatory action (McEwen et al., 2003), being highly available on the market. The current market price of echium oil is unknown since it is used as a source of SDA and C18:3n-3, but has been closely linked to the prices of the most common sources of C18:3n-3, including evening primrose (Oenothera biennis) and borage (Borago officinalis) oils (Berti et al., 2007).

In the present study, the effects of echium oil supplementation on methanogenesis were evaluated in RUSITEC, in comparison to those of positive (basal diet) and negative (BES) controls. Methane production was only detected on day 3 of the experimental period for the BES treatment (data not shown), as earlier observed by Karnati et al. (2009) with $250 \mu \mathrm{M}$ of BES, and suggesting an adaptation of the methanogenic population to the halogenated compound. Sodium 2-bromoethanesulfonate reduced methane production by $92.8 \%$, compared to the control, a similar finding (95\%) being described for the same supplementation level in vitro (Lee et al., 2009).

The depression in methane production by PUFA in vitro and in vivo is well established. In the present study, supplementation with $8 \%$ echium oil reduced daily methane production by $60 \%$, but the lower level $(4 \%)$ was unable to reduce methanogenesis. It is difficult to distinguish whether the effects of oil supplementation in methane mitigation are due to secondary metabolites, a particular fatty acid, or mixtures of fatty acids. Secondary compounds, like the pyrrolizidine alkaloids echimidine and echiumine, known to contribute to liver damage and photosensitivity in grazing livestock (Weston et al., 2013), are found in greatest quantity in E. plantagineum (Colegate et al., 2005). There are marked differences in the sensitivity of domestic species to echium toxicosis, with cattle and horses showing the highest levels of sensitivity (Cheeke, 1984). Although the rumen microorganisms that may be able to detoxify these alkaloids have not yet been identified, Wachenheim et al. (1992) found that jacobine biotransformation involves multiple bacterial species and Gram-positive bacteria can play a key role. However, as pyrrolizidine alkaloids are not lipophilic, they are not expected to be present in substantial quantities in the oil.
Echium oil contains relatively high levels of C18:3n-3, C18:4n-3, cis-9 C18:1 and C18:2n-6. Linoleic and $\alpha$-linolenic acids are known to reduce methane production, the latter having a more pronounced effect (Dohme et al., 2001). Recently, Amaro et al. (2012), using SDA inclusion levels up to $6.25 \mathrm{~g} \cdot \mathrm{kg}^{-1} \mathrm{TMR}$, failed to detect significant effects on methane production ( $\mathrm{mmol} \mathrm{g} \cdot \mathrm{kg}^{-1} \mathrm{DM}$ incubated), the higher level of supplementation corresponding to the SDA present in $4-5 \%$ of echium oil addition, toxic effects only being reported at supplementation levels of $30 \mathrm{~g} \mathrm{SDA} \cdot \mathrm{kg}^{-1}$ substrate DM and greater (Maia et al., 2012). Therefore, the present results obtained with $8 \%$ echium oil addition might be explained by a higher supply of PUFA, known to exert toxic effects on the rumen microbial population (Prins et al., 1972; Maia et al., 2007), greater effects being reported with increased unsaturation (Demeyer and Henderickx, 1967). Indeed, EO8 decreased the proportion of methanogens relative to rumen prokaryote 16S rDNA from effluents, the effect being similar to that for BES. The effect of lipid supplementation level (EO4 vs EO8) on the methanogen population was not observed in the solid samples (feed bag residues). Several studies (Hook et al., 2011; Lillis et al., 2011) have reported higher numbers of methanogens in rumen solids than in rumen liquid regardless of diet. However, diet may affect the distribution of methanogens between the solid- and liquid-phases of the rumen, with important implications for methanogenesis (McCartney et al., 2013). In the present study, despite not being significant, when compared to control, EO4 increased the proportion of methanogens in the effluents and decreased the proportion of methanogens in residues, suggesting a change in the microbial communities between liquid and solid phases. Indeed, diet has been suggested to mainly affect bacterial community abundance and diversity, whereas only the abundance, and not the diversity, of methanogens is affected (Lillis et al., 2011). Changes in bacterial populations might result in different fermentation patterns and therefore decreased methane production as a consequence of reduced substrate supply (hydrogen; Stewart et al., 1997). Despite the absence of effects of oil inclusion on total VFA production and DM and NDF digestibilities, echium oil increased the production of propionate (which is the main alternative sink for metabolic hydrogen during rumen fermentation), lowered the acetate:propionate ratio and decreased butyrate. 
A similar fermentation shift towards propionate production with lipid supplementation was reported in earlier studies (Wettstein et al., 2000).

\section{Conclusions}

The in vitro results suggest that echium oil supplementation is a promising natural strategy for enteric methane mitigation. However, the content of secondary metabolites, stearidonic and a mixture of PUFAs of echium oil may all have contributed to the observed effects of oil supplementation in methane mitigation.

\section{Acknowledgements}

Individual PhD Grant (SFRH/BD/47857/2008) to P. and Post-Doc grant (SFRH/BPD/ 70176/2010) to M.R.G. Maia from the Portuguese Foundation for the Science and Technology (FCT) (Portugal), are gratefully acknowledged. The authors would like to thank Dr. Susana Alves for the chromatographic analysis of fatty acids. They also acknowledge the help provided by Drs. Matt McCabe and Sinead Waters (Teagasc) with DNA isolation and qPCR, and the staff of the Nutrition Laboratory of AGROS/University of Porto for chemical analysis of feed samples. Authors are grateful to Dr. Keith Coupland (University of Hull, UK) for kindly providing the echium oil. This work has been supported by FCT through grant PEst-C/EQB/LA0006/2011 and partially financed by QREN Projects in CoPromotion - Incentive Scheme for Research and Technological Development (SI I\&DT; Project No. 5343, HealthyMilk), Operational Program Competitiveness Factors (COMPETE), European Fund for Regional Development (UE/FEDER).

\section{References}

Amaro P., Maia M.R.G., Dewhurst R.J., Fonseca A.J.M., Cabrita A.R.J., 2012. Effects of increasing levels of stearidonic acid on methane production in a rumen in vitro system. Anim. Feed Sci. Tech. 173, 252-260

AOAC, 1990. Association of Official Analytical Chemists. Official Methods of Analysis. 15th Edition. Arlington, VA

Balch W.E., Wolfe R.S., 1979. Transport of coenzyme M (2-mercaptoethanesulfonic acid) in Methanobacterium ruminantium. J. Bacteriol. 137, 264-273

Bernal-Santos G., O'Donnell A.M., Vicini J.L., Hartnell G.F., Bauman D.E., 2010. Hot topic: Enhancing omega-3 fatty acids in milk fat of dairy cows by using stearidonic acid-enriched soybean oil from genetically modified soybeans. J. Dairy Sci. 93, 32-37

Berti M., Johnson B.L., Dash S., Fischer S., Wilckens R., Hevia F., 2007. Echium: A source of stearidonic acid adapted to the northern great plains in the US. In: J. Janick, A. Whipkey (Editors). Issues in New Crops and New Uses. ASHS Press. Alexandria, VA (USA)
Brankatschk R., Bodenhausen N., Zeyer J., Bürgmann H., 2012. Simple absolute quantification method correcting for quantitative PCR efficiency variations for microbial community samples. Appl. Environ. Microbiol. 78, 4481-4489

Cabi, 2014. Invasive Species Compendium. In: http://www.cabi.org/isc

Calder P.C., 2006. n-3 Polyunsaturated fatty acids, inflammation, and inflammatory diseases. Amer. J. Clin. Nutr. 83, 1505S-1519S

Carberry C.A., Kenny D.A., Han S., McCabe M.S., Waters S.M., 2012. Effect of phenotypic residual feed intake and dietary forage content on the rumen microbial community of beef cattle. Appl. Environ. Microbiol. 78, 4949-4958

Cheeke P.R., 1984. Comparative toxicity and metabolism of pyrrolizidine alkaloids in ruminants and nonruminant herbivores. Can. J. Anim. Sci. 64, 201-202

Colegate S.M., Edgar J.A., Knill A.M., Lee S.T., 2005. Solid-phase extraction and HPLC-MS profiling of pyrrolizidine alkaloids and their N-oxides: a case study of Echium plantagineum. Phytochem. Analysis 16, 108-119

Czerkawski J.W., 1986. An introduction to rumen studies. Pergamon Press, Oxford (UK)

Czerkawski J.W., Blaxter K.L.,Wainman F.W., 1966. The metabolism of oleic, linoleic and linolenic acids by sheep with reference to their effects on methane production. Brit. J. Nutr. 20, 349-362

Czerkawski J.W., Breckenridge G., 1977. Design and development of a long-term rumen simulation technique (Rusitec). Brit. J. Nutr. 38, 371-384

Demeyer D.I., Henderickx H.K., 1967. The effect of C18 unsaturated fatty acids on methane production in vitro by mixed rumen bacteria. Biochim. Biophys. Acta 137, 484-497

Denman S.E., Tomkins N.W., McSweeney C.S., 2007. Quantitation and diversity analysis of ruminal methanogenic populations in response to the antimethanogenic compound bromochloromethane. FEMS Microbiol. Ecol. 62, 313-322

Dohme F., Machmüller A., Wasserfallen A., Kreuzer M., 2001. Ruminal methanogenesis as influenced by individual fatty acids supplemented to complete ruminant diets. Lett. Appl. Microbiol. $32,47-51$

Edwards J.E., McEwan N.R., McKain N., Walker N., Wallace R.J., 2005. Influence of flavomycin on ruminal fermentation and microbial populations in sheep. Microbiology 151, 717-725

Guil-Guerrero J.L., 2007. Stearidonic acid (18:4n-3): Metabolism, nutritional importance, medical uses and natural sources. Eur. J. Lipid Sci. Tech. 109, 1226-1236

Hook S., Steele M., Northwood K., Wright A.D., McBride B., 2011. Impact of high-concentrate feeding and low ruminal $\mathrm{pH}$ on methanogens and protozoa in the rumen of dairy cows. Microbial Ecol. 62, 94-105

Johnson K.A., Johnson D.E., 1995. Methane emissions from cattle. J. Anim. Sci. 73, 2483-2492

Karnati S.K.R., Sylvester J.T., Ribeiro C.V.D.M., Gilligan L.E., Firkins J.L., 2009. Investigating unsaturated fat, monensin, or bromoethanesulfonate in continuous cultures retaining ruminal protozoa. I. Fermentation, biohydrogenation, and microbial protein synthesis. J. Dairy Sci. 92, 3849-3860

Kitessa S.M., Young P., 2011. Enriching milk fat with $n-3$ polyunsaturated fatty acids by supplementing grazing dairy cows with ruminally protected Echium oil. Anim. Feed Sci. Tech. 170, 35-44

Kitessa S.M., Abeywardena M., Wijesundera C., Nichols P.D., 2014. DHA-containing oilseed: A timely solution for the sustainability issues surrounding fish oil sources of the health-benefitting long-chain omega-3 oils. Nutrients 6, 2035-2058 
Lee S.Y., Yang S.H., Lee W.S., Kim H.S., Shin D.E., Ha J.K., 2009. Effect of 2-bromoethanesulfonic acid on in vitro fermentation characteristics and methanogen population. Asian-Austr. J. Anim. Sci. 22, 42-48

Lillis L., Boots B., Kenny D.A., Petrie K., Boland T.M., Clipson N., Doyle E.M., 2011. The effect of dietary concentrate and soya oil inclusion on microbial diversity in the rumen of cattle. J. Appl. Microbiol. 111, 1426-1435

Machmüller A., Ossowski D.A., Wanner M., Kreuzer M., 1998. Potential of various fatty feeds to reduce methane release from rumen fermentation in vitro (Rusitec). Anim. Feed Sci. Tech. 71, $117-130$

Maia M.R.G., Chaudhary L.C., Figueres L., Wallace R.J., 2007. Metabolism of polyunsaturated fatty acids and their toxicity to the microflora of the rumen. Anton. Leeuwenhoek 91, 303-314

Maia M.R.G., Correia C.A.S., Alves S.P., Fonseca A.J.M., Cabrita A.R.J., 2012. Technical note: Stearidonic acid metabolism by mixed ruminal microorganisms in vitro. J. Anim. Sci. 90, 900-904

Martin C., Morgavi D.P., Doreau M., 2010. Methane mitigation in ruminants: from microbe to the farm scale. Animal 4, 351-365

McCartney C.A., Bull I.D., Dewhurst R.J., 2013. Chemical markers for rumen methanogens and methanogenesis. Animal 7 , 409-417

McDougall E.I., 1948. Studies on ruminant saliva. 1. The composition and output of sheep's saliva. Biochem. J. 43, 99-109

McEwen A.B., Whittle E.B., Parsons R.G., McCurrie K., 2003. C-14 -Glyphosate: Uptake into Echium plantagineum following preemergent application. In: Proceedings of Brighton Crop Protection International Congress: Crop Science \& Technology. Glasgow (UK), pp. 883-886

Mozaffarian D., 2008. Fish and $n-3$ fatty acids for the prevention of fatal coronary heart disease and sudden cardiac death. Amer. J. Clin. Nutr. 87, 1991S-1996S

Muyzer G., de Waal E.C., Uitterlinden A.G., 1993. Profiling of complex microbial populations by denaturing gradient gel electrophoresis analysis of polymerase chain reaction-amplified genes coding for 16S rRNA. Appl. Environ. Microbiol. 59, 695-700
Prins R.A., Nevel C.J., Demeyer D.I., 1972. Pure culture studies of inhibitors for methanogenic bacteria. Anton. Leeuwenhoek $38,281-287$

Stewart C.S., Flint H.J., Bryant M.P., 1997. The rumen bacteria. In: P.N. Hobson (Editor). The Rumen Microbial Ecosystem. Chapman and Hall, London (UK), pp. 10-72

Surette M.E., Edens M., Chilton F.H.,Tramposch K.M., 2004. Dietary echium oil increases plasma and neutrophil long-chain ( $n-3)$ fatty acids and lowers serum triacylglycerols in hypertriglyceridemic humans. J. Nutr. 134, 1406-1411

Wachenheim D.E., Blythe L.L., Craig A.M., 1992. Characterization of rumen bacterial pyrrolizidine alkaloid biotransformation in ruminants of various species. Vet. Human Toxicol. 34, 513-517

Wang L.A., Goonewardene Z., 2004. The use of MIXED models in the analysis of animal experiments with repeated measures data. Can. J. Anim. Sci. 84, 1-11

Weston P.A., Weston L.A., Hildebrand S., 2013. Metabolic profiling in Echium plantagineum: presence of bioactive pyrrolizidine alkaloids and napthoquinones from accessions across southeastern Australia. Phytochem. Rev. 12, 831-837

Wettstein H.R., Machmüller A., Kreuzer M., 2000. Effects of raw and modified canola lecithins compared to canola oil, canola seed and soy lecithin on ruminal fermentation measured with rumen simulation technique. Anim. Feed Sci. Tech. 85, 153-169

Yamazaki K., Fujikawa M., Hamazaki T., Yano S., Shono T., 1992. Comparison of the conversion rates of a-linolenic acid (18:3(n-3)) and stearidonic acid $(18: 4(n-3))$ to longer polyunsaturated fatty acids in rats. Biochim. Biophys. Acta 1123, 18-26

Yu Z., Morrison M., 2004. Improved extraction of PCR-quality community DNA from digesta and fecal samples. Biotechniques 36, 808-812

Zhang C.M., Guo Y.Q., Yuan Z.P., Wu Y.M., Wang J.K., Liu J.X., Zhu W.Y., 2008. Effect of octadeca carbon fatty acids on microbial fermentation, methanogenesis and microbial flora in vitro. Anim. Feed Sci. Tech. 146, 259-269

Zhang D.F., Yang H.J., 2011. Combination effects of nitrocompounds, pyromellitic diimide, and 2-bromoethanesulfonate on in vitro ruminal methane production and fermentation of a grain-rich feed. J. Agr. Food Chem. 60, 364-371 